\title{
Chinese State-owned Enterprises and Human Rights The Importance of National and Intra-organizational Pressures
}

Whelan, Glen; Muthuri, Judy N.

Document Version

Accepted author manuscript

Published in:

Business \& Society

DOI:

$10.1177 / 0007650315612399$

Publication date:

2017

License

Unspecified

Citation for published version (APA):

Whelan, G., \& Muthuri, J. N. (2017). Chinese State-owned Enterprises and Human Rights: The Importance of National and Intra-organizational Pressures. Business \& Society, 56(5), 738-781.

https://doi.org/10.1177/0007650315612399

Link to publication in CBS Research Portal

\section{General rights}

Copyright and moral rights for the publications made accessible in the public portal are retained by the authors and/or other copyright owners and it is a condition of accessing publications that users recognise and abide by the legal requirements associated with these rights.

Take down policy

If you believe that this document breaches copyright please contact us (research.lib@cbs.dk) providing details, and we will remove access to the work immediately and investigate your claim. 


\title{
Chinese State-owned Enterprises and Human Rights: The Importance of National and Intra-organizational Pressures Glen Whelan and Jude N. Muthuri
}

\author{
Journal article (Post print version)
}

\section{Whelan, Glen; Gond, Jean-Pascal, Chinese State-owned Enterprises and Human Rights: The} Importance of National and Intra-organizational Pressures, Business \& Society (Vol. 56, №. 5) pp. 738-781.

DOI: 10.1177/0007650315612399

Copyright (ㄱ २०१८ (The Authors). Reprinted by permission of SAGE Publications.

Uploaded to Research@CBS: June २०17 


\title{
Chinese State-Owned Enterprises and Human Rights:
}

\section{The Importance of National and Intra-Organizational Pressures}

\author{
Forthcoming: Business \& Society \\ Authors: Glen Whelan \& Judy Muthuri \\ Contact Author: Glen Whelan \\ gw.msc@cbs.dk
}

Acknowledgements:

We gratefully acknowledge the constructive comments made on earlier versions of this article by the editorial team and two anonymous reviewers. We thankfully acknowledge financial support received from University of Nottingham New Researchers Fund, and research assistance from Angela Shen and Biswaraj Ghosh. Glen Whelan thankfully acknowledges support received from the RBB project whilst a Visiting Associate Professor at Copenhagen Business School in 2013. 


\title{
Chinese State-Owned Enterprises and Human Rights:
}

\section{The Importance of National and Intra-Organizational Pressures}

\begin{abstract}
The growing global prominence of Chinese state-owned enterprises (SOEs) makes it increasingly important to recognize that multinational corporations (MNCs) can be subject to conflicting human rights pressures at the transnational, national, and intra-organizational levels. We here construct a three-level framework that maps these various human rights pressures, and use it to identify and analyse the human rights that Chinese SOEs report concern with. Our analysis suggests that whilst China's most global SOEs are subject to transnational pressures to respect all human rights, such pressures appear outweighed by those encouraging them to concentrate upon only some human rights - i.e. economic, social and cultural rights - within their national and intra-organizational environment. We conclude by identifying a number of ways in which our conceptual framework and empirical findings can inform future research.
\end{abstract}




\section{Chinese State-Owned Enterprises and Human Rights:}

\section{The Importance of National and Intra-Organizational Pressures}

The human rights relevant policies and practices of multinational corporations (MNCs) are increasingly discussed within a number of overlapping literatures: e.g. business and society, business ethics, corporate social responsibility (CSR), international law (Wettstein, 2012). By and large, these writings concentrate on normatively prescribing the human rights obligations of MNCs (e.g. Arnold, 2010), and/or, on describing the ways in which changes in the global environment have contributed to human rights and CSR concerns becoming increasingly connected (e.g. Kobrin, 2009). In particular, the development of the United Nations' (UN) Guiding Principles on Business and Human Rights (Ruggie, 2011), and the framework upon which they are based - which posits that MNCs have the duty to 'respect' human rights, and that states have the duty to 'protect' human rights and 'remedy' human rights concerns (Ruggie, 2008) - have been the subject of considerable commentary (e.g. McCorquodale, 2009; Whelan, Moon \& Orlitzky, 2009).

Although the broad literature on MNCs and human rights is marked by increasing sophistication, it arguably lacks nuance when it comes to acknowledging that MNCs are commonly subject to competing human rights pressures. Indeed, even those who argue that MNCs operate within fragmented institutional environments, and that MNCs face different CSR pressures (e.g. pressures regarding animal rights, climate change, corruption, sweatshops) at different levels of analysis, tend to emphasize that MNCs operate within an environment that acknowledges and promotes the universality of human rights in a more or less univocal fashion (Aguilera, Rupp, Williams \& Ganapathi, 2007: 852; Kostova, Roth \& Dacin, 2008: 998).

Two overlapping considerations help explain this emphasis. First, the literature on CSR - and 'political' CSR as opposed to political CSR in particular (see Whelan, 2012) - has tended to argue that we now live in a world in which local and national pressures are of decreasing importance, and in which transnational pressures from transnational actors who commonly advocate and promote human rights (e.g. international non-government organizations like Amnesty International, intergovernmental organizations like the UN), are increasingly important (e.g. Scherer \& Palazzo, 2011). 
Second, there has been a tendency for the MNC and human rights literature to concentrate on the policies and practices of MNCs with Western 'home' states. These 'home' states - and the citizens thereof - often promote the universality of human rights even though they are not necessarily paragons of virtue with regards thereto, or even signatories to all of the major human rights initiatives. Thus, the United States (US) government obviously played a key role in establishing the Universal Declaration of Human Rights, but is yet to ratify one of its major 'offshoots': i.e. the International Covenant on Economic, Social and Cultural Rights (ICESCR, 1966). More specifically, the US government has played a key role in "promoting various voluntary CSR initiatives" (Aguilera et al. 2007: 849), multi-stakeholder initiatives (Rasche, 2012) and/or international accountability standards (Gilbert, Rasche \& Waddock, 2011) that promote human rights, and that US (and other) MNCs commonly participate within: e.g. the Voluntary Principles on Security and Human Rights, which is focused on the extractive industries; and the Global Network Initiative, which is focused on information and communication technology companies.

The point being made is that, whilst "the multiplicity of actors currently involved in... global [CSR] accountability standards" has been noted more generally (Jamali, 2010: 628), the multiplicity of voices that exist with regard to the human rights responsibilities of MNCs, remains largely ignored. More specifically - and whilst the MNC-human rights problematic is underpinned by the fact that various nation-states are unable or unwilling to promote human rights domestically - there is a common presumption that national and transnational pressures strongly encourage MNCs to at least profess their concern to 'fill' these 'governance gaps' (Ruggie, 2008).

As has recently been suggested, however, this general understanding is rendered increasingly problematic by the re-emergent power of non-Western countries that do not always acknowledge the universality of human rights, and that commonly emphasize the importance of state sovereignty (e.g. Chan, Lee \& Chan, 2008; Waddock, 2008: 106). Further, it is rendered problematic by the fact that MNCs are themselves conceivable as intra-organizational environments, and that pressures there within need not be consistent with those of their transnational environment (Kostova, Roth \& Dacin, 2008). 
With such concerns in mind, we use the present paper to identify and analyse the competing pressures that Chinese state-owned enterprises (SOEs) are currently subject to with regards to human rights responsibilities. Most notably, and on the basis of our empirical analysis of their reported human rights concerns, we argue that the transnational pressures that encourage Chinese SOEs to acknowledge all human rights are currently outweighed by those encouraging them to concentrate upon only some human rights within their national and intra-organizational environment.

In making our argument, we structure the paper as follows. First, we draw on the business ethics, CSR and institutional theory literatures to construct a three-level framework for mapping the various human rights pressures that MNCs are subject to. Importantly, we recognize that because MNCs have headquarters in their home states and subsidiaries in host states (Kobrin, 2009: 356-358), the transnational, national and intra-organizational levels we distinguish between are more or less always interrelated. Second, we apply our framework to Chinese SOEs affiliated with the central arm of SASAC (i.e. the State Asset Supervision and Administration Commission of the State Council), and suggest that whilst Chinese SOEs are subject to similar transnational human rights pressures as all other MNCs, they are also subject to specific and overlapping national and intra-organizational human rights pressures as a result of their being controlled by the Chinese Communist Party (CCP) (Chan, 2009). More substantively, we argue that whereas the transnational CSR environment is characterized by pressures emphasizing the importance of all human rights: i.e. those contained within both the International Covenant on Civil and Political Rights (ICCPR, 1966) and the International Covenant on Economic, Social and Cultural Rights (ICESCR, 1966); the national and intra-organizational network of Chinese SOEs is only characterized by pressures emphasizing the importance of some human rights: i.e. those within the ICESCR.

With the context so detailed, we then outline our methods; discuss our findings with regard to the reported human rights commitments of China's ten most global SOEs as measured by their outward stock of foreign direct investment in 2006 (OECD, 2008); and argue that the SOEs appear less influenced by the pressures of the transnational environment than they do their national and intraorganizational environment. Finally, we discuss the wider importance of our findings, and make a number of suggestions as to how they can inform future research. 


\section{THREE LEVELS OF HUMAN RIGHTS PRESSURES: A FRAMEWORK}

MNCs face various pressures to discharge a variety of responsibilities with regard to human rights. Whilst the full extent of these duties is the subject of an important normative debate (e.g. Smith, 2013; Wettstein, 2012, 2013; Whelan, 2012, 2013), we are here interested in the positive (i.e. descriptive or explanatory) aspects of MNCs and human rights theorizing. In particular, we use the present section to differentiate between three levels at which human rights pressures exist with regard to MNCs: i.e. the transnational, national and intra-organizational levels respectively.

In writing of pressures, we refer to the ways in which different actors seek to force or encourage MNCs to comply with a given set of behavioural norms, to reconstruct or amend their policies, and/or, to somehow alter their practices (Oliver, 1991; see also Jamali, 2010). Such pressures can be driven (or motivated) by various considerations (e.g. aesthetic, instrumental, moral), and can take various forms (e.g. they can be more coercive or persuasive). Further, different pressures can be complementary (e.g. human and labour rights) or conflicting (e.g. pressures relating to animal rights and the professional interests of abattoir workers), and will often be resisted.

In writing of human rights pressures more specifically, we refer to the fact that MNCs are currently subject to various pressures that encourage them to impact upon human rights in various ways. Whilst these pressures can take numerous forms - e.g. laws, moral arguments, pragmatic demands - we are most concerned with their scope in the present paper. Specifically, we distinguish between those pressures that encourage MNCs to respect all of the rights, and those that encourage MNCs to respect only some of the rights, listed within the 'International Bill of Human Rights': i.e. the Universal Declaration of Human Rights (1948), the International Covenant on Civil and Political Rights (ICCPR, 1966), and the International Covenant on Economic, Social and Cultural Rights (ICESCR, 1966) (Morsink, 1999).

To be clear as to what we mean in these regards, we emphasize three points. First, we note that, whilst human rights duties, and civil and political rights in particular, are most clearly associated with states (Whelan, Moon \& Orlitzky, 2009), it is increasingly recognized that MNCs can enable or undermine what amounts to all human rights, in a direct or indirect fashion (Ruggie, 2011). To quickly illustrate, we highlight that many MNCs (e.g. Coca-Cola) now have policies that prohibit the 
use of forced labour within their supply chains; and that various MNCs (e.g. Shell, Statoil) have guidelines on how to responsibly 'manage' the involuntary resettlement (or forced displacement) of peoples. In short, MNCs increasingly recognize responsibilities for human rights concerns that, until recent times, were generally considered the exclusive domain of states.

Second, we note that notions of state sovereignty can conflict with pressures encouraging MNCs to promote or respect all human rights. In other words, we recognize that MNCs, and other organizational actors, are also subject to pressures that promote the ability of states to set laws within their borders, and that enable them to 'pick and choose' between the human rights they wish to promote and/or respect. Further, we recognize that different actors - e.g. the Organisation for Economic Cooperation and Development (OECD), the UN - sometimes promote, in a seemingly contradictory fashion, both all human rights and state sovereignty (OECD, 2011; UN, 1945).

Finally, we recognize that MNCs can be directly and indirectly responsible for undermining or disrespecting human rights. MNCs are directly responsible for human rights abuses when their immediate activities (e.g. their employment contracts) are the source of concern. When, on the other hand, they are indirectly involved in "human rights abuses" - i.e. "where the actual harm is committed by another party, including governments and non-State actors" that they are (contractually) involved with - they can be said to be complicit (Ruggie, 2008: paras. 73-81). Whilst it might be thought that MNCs are more likely to be subject to human rights pressures that relate to their direct than indirect responsibilities, this is not necessarily the case. Many multi-stakeholder initiatives for instance - such as the Voluntary Principles on Security and Human Rights and the Global Network Initiative - are concerned with encouraging MNCs to avoid being complicit in (civil and political) human rights abuses; and many MNCs (e.g. Coca-Cola) clearly note their concern to avoid being complicit for a whole variety of (civil and political) human rights (e.g. the right to not be subjected to slavery). Accordingly, we do not here distinguish between direct and indirect human rights responsibilities; and do not make any suggestions as to whether or not MNCs are more likely to be directly or indirectly responsible for one human right or another. Rather, we simply conceive of human rights pressures as encompassing those pressures that relate to the posited direct and indirect responsibilities of MNCs more generally (e.g. Ruggie, 2008). 


\section{Transnational Human Rights Pressures}

Transnational human rights pressures transcend the confines of, or are not simply associated with actors from, a given nation-state. They tend to derive from intergovernmental organizations, international non-government organizations (NGOs), and new governance structures such as multistakeholder initiatives and/or international accountability standards (e.g. Aguilera et al., 2007: 850853; Gilbert, Rasche \& Waddock, 2011; Rasche, 2012). Given the continued absence of a global sovereign, and the difficulties of reaching agreement on matters of international law, transnational human rights pressures rarely take a 'hard' or coercive form. Rather, they tend to be of a 'softer' status, and/or, tend to encourage national actors to impose 'harder' pressures upon those actors that national actors can control (Kobrin, 2009: 361).

Prominent examples of international NGOs who encourage MNCs to acknowledge and further human rights include Amnesty International and Human Rights Watch. Prominent examples of transnational initiatives that pressure MNCs to address human rights (and that international NGOs are commonly involved in more or less directly), include the OECD Guidelines for Multinational Enterprises (OECD, 2011), the UN Global Compact (UNGC), and the UN Guiding Principles on Business and Human Rights (Ruggie, 2011). The UN Guiding Principles have recently been termed the "state of the art in the debate on business and human rights" (Wettstein, 2012: 741). They thus provide a good example of the manner in which transnational human rights pressures commonly encourage MNCs to acknowledge, and act upon, the importance of all human rights. As the twelfth Guiding Principle states:

"Because business enterprises can have an impact on virtually the entire spectrum of internationally recognized human rights, their responsibility to respect allies to all such rights... An authoritative list of the core internationally recognized human rights is contained in the International Bill of Human Rights...., coupled with the principles concerning fundamental rights in the eight ILO [International Labour Organization] core conventions as set out in the Declaration on Fundamental Principles and Rights at Work” (Ruggie, 2011). 
Given that the normative merits of the 'Protect, Respect and Remedy' framework underpinning the Guiding Principles are discussed elsewhere (see above), and given our current concern with positive theorizing, only a number of overlapping points need to be noted with regard to the framework here. First, in advocating that MNCs (and other business enterprises) should 'respect' human rights, Ruggie emphasizes that MNCs should "do no harm" (Ruggie, 2008: para. 24). Thus, and whilst this posited duty requires MNCs to take positive steps to ensure that they avoid being directly or indirectly responsible for human rights abuses, it is basically a negative duty that does not require MNCs to ensure that human rights are 'protected', and human rights concerns 'remedied'.

The duty to 'protect' and 'remedy', on the other hand, falls to states (Ruggie, 2008). To discharge these two duties - i.e. to protect human rights and remedy human rights concerns as they relate to MNCs - states are required to put measures in place that encourage (or force) MNCs to 'respect' human rights, and to establish institutional structures that are capable of redressing those instances in which such 'respect' is lacking. Importantly, the state duty to 'protect' human rights is arguably most pronounced with regard to SOEs for:

"In principle, inducing a rights-respecting corporate culture should be easier to achieve in Stateowned enterprises (SOEs). Senior management in SOEs is typically appointed by and reports to State entities. Indeed, the State itself may be held responsible under international law for the internationally wrongful acts of its SOEs if they can be considered State organs or are acting on behalf, or under the orders, of the State" (Ruggie, 2008: para. 32).

Whilst we consider the UN Guiding Principles a good illustration of the fact that MNCs are subject to transnational pressures to acknowledge (and somehow promote) all human rights, we note that various actors are commonly critical of their underlying 'Protect, Respect and Remedy' framework (see Whelan, Moon \& Orlitzky, 2009). MNC and human rights scholars such as Arnold (2010) and human rights NGOs such as Amnesty International, for example, have expressed concern as to what Wettstein (2012) suggests are the relatively modest demands that Ruggie's framework makes of MNCs and states. Nevertheless, many of these same critics agree that Ruggie's framework is right to emphasize the importance of all human rights. 


\section{National Human Rights Pressures}

As the label suggests, national human rights pressures are those that are more or less readily associated with a given state, and/or, with a given national population. In terms of the later, it is clearly possible for a given population to place normative and/or material pressure on MNCs to acknowledge and act upon a set of human rights duties: e.g. through consumer boycotts, media advocacy, protests and so on. Further, it is obviously possible for specific elements of a population to place such pressure on MNCs: e.g. activists and NGOs from within a given country.

Whilst the pressures that a national population (or parts thereof) put on MNCs are important, the human rights pressures that states (or governments) can put on MNCs are often more immediate, and less diffuse, due to states being in a position to coerce, or strongly encourage, MNCs, to discharge various human rights duties (e.g. Aguilera et al. 2008: 848). Amongst other things, states can encourage and/or require MNCs to report on their human rights policies and practices as a means by which to encourage a 'rights respecting' culture (Ruggie, 2008: para. 30). Further, states can align the awarding of government contracts with the need for strong human rights policies and practices; and they can seek to ensure that their national laws, and the international regimes they participate within more generally, encourage MNCs to respect all human rights (e.g. Ruggie, 2011).

Given that different states can put various pressures on corporations more generally, we emphasize that we here conceive of national pressures as only relating to the efforts that states make to impact upon the human rights performance of 'home' MNCs: i.e. MNCs whose 'parent' is incorporated within, or has headquarters (HQ) within, their national boundaries. Further, we emphasize that, because MNCs have a 'home' state - i.e. the country where their HQ is incorporated/located - and 'host' states - i.e. the foreign countries where their subsidiaries are located (e.g. Zerk, 2006: 51-52) these national pressures will commonly transcend national boundaries, and have what can be conceived of as an 'extraterritorial effect' (Ruggie, 2008: para. 14). On the other hand, our conception of national pressures does not include the pressures that host states put on 'non-home' MNCs: i.e. MNCs with subsidiaries, but not HQs, located within their borders. We suggest that such pressures are better conceived of as foreign pressures. Further, we note that whilst such foreign pressures are often important, we do not account for them in our analysis below. 
In addition to their morally benefitting from the inherent value of doing the 'right' thing, states can potentially derive materially benefit - e.g. in terms of national competitiveness, risk minimization by pressuring their home MNCs to respect all human rights (e.g. Aguilera et al. 2007: 848-850; Ruggie, 2008: paras. 27, 32; Ruggie, 2011: prin. 2). Whilst states such as the US (Clinton, 2010) and UK (UKFCO, 2011: 71) commonly suggest that they follow this general logic, many do not.

The CCP, for instance, can only ever mention the universality and indivisibility of human rights at the risk of self-contradiction, and thus tends to suggest that different societies should emphasise different, or some, human rights, as a result of their differing cultural, economic and political contexts (e.g. Deng, 2008, pp. 271-272). State sovereignty, on the other hand, is an ideal that is broadly aligned with the CCP's interests. Accordingly, the CCP tends to emphasize state sovereignty alongside the importance of some more than all human rights, in its various global governance statements and activities (e.g. Chan, Lee \& Chan, 2008), and in the pressures it places on Chinese MNCs (see below).

\section{$\underline{\text { Intra-Organizational Human Rights Pressures }}$}

In addition to being situated within transnational and national environments, "all units in MNCs" i.e. both MNC HQs and their foreign subsidiaries - can be "viewed as belonging to the same intraorganizational institutional field, which is contained within the boundaries of the firm" (Kostova, Roth \& Dacin, 2008: 998). Such fields are generally easy to recognize: for they are characterized by "formal authority structure[s]" in which "subunits are... dependent on the parent company... for critical resources" (Kostova, Roth \& Dacin, 2008: 998).

In light of such, the key point to emphasize is that MNCs as a whole, and/or their separate subunits, will more or less always face some sort of internal pressures that encourage them to manage their response to external (e.g. national or transnational) pressures. Most generally, we note that internal pressures relating to such things as profitability, reputation and risk management, and ultimately, owner and/or managerial interests, can often encourage MNCs to 'decouple' (Meyer \& Rowan, 1977) their actual practices from the various international accountability standards that external pressures (e.g. from international non-government organizations) encourage them to join (Jamali, 2010). 
Just as national pressures commonly derive from the moral and material objectives of nationstates, so too do intra-organizational pressures commonly derive from the moral and material objectives, and get shaped by the corporate governance structures (Aguilera \& Jackson, 2003), of an MNC's HQ. Amongst other things then, and as with CSR policies and practices more generally (Whelan, 2012: 716-718), the human rights policies and practices of MNCs tend to be strongly influenced by their owners' interests and their formal organizational apparatus.

As these points suggest, an understanding of the intra-organizational environment of an SOE needs to more or less directly account for the interests (material and/or moral) of the owning nation-state (e.g. Aguilera \& Jackson, 2010: 523; Néron \& Norman 2008: 8; Shen \& Lin, 2009: 444). Furthermore, we suggest that SOEs will be confronted with intra-organizational pressures - that may or may not be consistent with national and transnational pressures - to acknowledge either all or some of the human rights listed in the International Bill of Rights.

The interrelated nature of all these different pressures is illustrated with figure 1 below.

-- Insert Figure 1 about Here --

\section{PLACING CHINESE STATE-OWNED ENTERPRISES WITHIN THE THREE-LEVEL}

\section{FRAMEWORK}

Although there is an emerging body of work on China and CSR (e.g. Kong, Liu \& Dai, 2012; Moon \& Shen, 2010; Noronha, Tou, Cynthia \& Guan, 2013), the relationship between Chinese SOEs and human rights remains largely unexplored. Further, the wider business and society literature is yet to reflect the growing global prominence of Chinese SOEs (e.g. Fortune, 2013; UNCTAD, 2011). Accordingly, our research focuses on those Chinese SOEs placed under the control of SASAC: i.e. the State Asset Supervision and Administration Commission of the State Council (of the People's Republic of China) that was established to perform the "responsibilities of investor" for China's leading and most international SOEs (SASAC, 2003; also see Naughton, 2011: 317-318). At the time of writing, SASAC is the nominal owner of $\sim 120$ of China's largest SOEs, and the nominal owner of the vast majority of the 95 Chinese MNCs featured on the Fortune Global 500 in 2013. SASAC SOEs are thus an important part of the global economic landscape. 


\section{$\underline{\text { Transnational Human Rights Pressures }}$}

Like other MNCs, SASAC SOEs are embedded within the broader transnational environment, and are ultimately subject to pressures to respect all human rights (e.g. Brownell, 2012). More specifically, various SASAC SOEs (e.g. PetroChina, Sinopec Group, China Mobile Communications Corporation) are currently members of the UNGC: a transnational CSR initiative that encourages MNCs (and other businesses) to respect all human rights (see table 1 below). Further, Chinese SOEs are commonly subject to pressure from transnational human rights activists. China National Petroleum Corporation (CNPC) for example, remains subject to considerable pressure from transnational activists concerned to promote all human rights given their controversial (and continuing) activities in Sudan (e.g. Patey, 2007, 2009). On the other hand, we also emphasize that because SASAC SOEs are commonly not involved in more specific sector-focused human rights multi-stakeholder initiatives such as the Voluntary Principles on Security and Human Rights (which is directed towards the extractives sector) or the Global Network Initiative (which is directed towards information and communication technology MNCs) - they are arguably subject to less transnational human rights pressures than their foreign counterparts (see Chan, Lee \& Chan, 2008).

\section{National Human Rights Pressures}

Whereas SASAC SOEs are subject to transnational pressures that encourage them to acknowledge (and/or somehow promote) all human rights, they are only subject to pressures that encourage them to acknowledge some human rights at the national level. The Chinese national population for instance, appears to have "a clear preference for stability and economic growth, even if that means postponing democracy and tolerating for the time being greater restrictions of civil and political rights" (Peerenboom, 2007: 156). They also appear to have "a high degree of trust in the ability of the central government to manage the problems the country faces" (Fewsmith, 2008: 214).

In addition to the Chinese population arguably having a somewhat limited interest in the (national or transnational) promotion of all human rights, the CCP has obvious reasons for being more or less opposed thereto. Indeed, in legitimizing a monist political system that formally recognizes "the hegemony of the CCP" (Burns, 1999: 581), China's constitution directly opposes democratic (multiparty) political structures that respect for all human rights entails (e.g. Morsink, 1999). 
Further to a multitude of other considerations then - e.g. China was subject to a 'century of humiliation' (1842-1949) at the hands of colonial (and imperial) Western powers who now tend to champion the importance of all human rights - the CCP's control of China's monist political system helps explain why it is yet to ratify the ICCPR (which is the covenant of the International Bill of Rights most readily associated with democratic political structures), and why it strongly champions respect for state sovereignty. On the other hand, the fact that the CCP's political legitimacy relates to its furthering a whole host of social and economic rights (e.g. Shambaugh, 2008: 168-169), helps explain why it has ratified the ICESCR (Whelan, Moon \& Orlitzky, 2009: 370).

As with our discussion of the pressures to comply with all human rights at the transnational level, a fuller discussion as to why the Chinese party-state only emphasizes some human rights is beyond the scope of the present paper. What we do need to note however, is that the CSR guidelines that SASAC released in 2008 reflect the CCP's more general concern with economic and social rights, and their relative lack of concern with civil and political rights. In particular, we note that the guidelines:

1. Never state that Chinese SOEs need to respect all human rights (and never actually mention 'human rights' at all);

2. Clearly emphasize economic and social rights when they write of labour rights, sustainable development and "the socialist harmonious society" for example;

3. Understate or ignore the importance of civil and political rights (e.g. they never mention such things as 'freedom of association'); and

4. Link CSR to China's national interest when they state that the practice of CSR by Chinese SOEs will help "China to spread an image as a responsible nation" (SASAC, 2008).

As these four points succinctly indicate, the Chinese national environment differs from the transnational environment in that it does not pressure Chinese SOEs to acknowledge the importance of all human rights, but only some human rights: i.e. those listed in the ICESCR.

\section{Intra-Organizational Human Rights Pressures}

In addition to being part of the Chinese national environment, SASAC can be conceived as part of an intra-organizational environment that is comprised of itself and the SOEs it nominally owns. Further to various other mechanisms that are controlled by the CCP - e.g. the nomenklatura system of 
hierarchically appointing party personnel (Downs, 2008: 123-124; McGregor, 2010: 72); various accounting and financial bodies (Noronha et al., 2013) - SASAC strives to ensure that managerial decision making within China's most important SOEs is aligned with the interests of the CCP (Chan, 2009: 50; Downs, 2008: 125). More specifically - and in duly noting that SASAC cannot always enforce their will upon managers within the SOEs they nominally own - we suggest that SASAC occupy the top position of the Chinese SOE intra-organizational environment.

SOE HQs occupy the second level. These SOEs are $100 \%$ owned by the Chinese party-state (and nominally owned by SASAC). Just as with SASAC, the leading managers of China's parent SOEs are in effect always leading members of the CCP who have previously been employed in various partystate roles. Importantly, when it is felt that these leaders somehow undermine CCP interests (or those of powerful opponents within the (CP), they are 'dealt with' accordingly. To provide just one example, we note that Jiang Jiemin - the former director of SASAC and full member of the CCP $18^{\text {th }}$ Central Committee (and previous CEO of CNPC and Chairman of PetroChina) (www.chinavitae.com) - was recently sacked as a result of corruption charges, and/or, in an effort to eliminate "vested interests in state-owned industries [that] have long been seen as opposed to economic reform..." (BBC, 2013).

Finally, we place the immediate subsidiaries of the SOE HQs at the third level of the intraorganizational environment. Although these subsidiaries are commonly listed on foreign stock exchanges, their HQs hold the vast majority of their shares, and are often managed by the same people that head the parent company. Given that the subsidiaries of Chinese SOE HQs often have their own subsidiaries, we note that we do not go beyond this third level of analysis here.

More generally, we emphasize that a key benefit of conceiving the Chinese SOE intraorganizational environment in terms of these three levels, is that it highlights that SASAC SOEs are part of a national-intra-organizational hybrid environment that is ultimately controlled by the CCP's leading body: i.e. the Politburo Standing Committee (e.g. Shambaugh, 2008; Shirk, 1993). Furthermore, it highlights that this environment is overlaid with "formal authority structure[s]" (Kostova, Roth \& Dacin, 2008: 998) that seek to ensure the influence of CCP interests at every opportunity. 


\section{METHOD}

To examine whether or not China's SASAC SOEs are more influenced by their transnational, national, and/or intra-organizational environments, we analysed human rights related disclosures within documents and websites published by China's ten (10) most 'internationalised' parent SOEs (as of 2006), and their thirty-four (34) immediate and listed subsidiaries (OECD, 2008). As depicted in Table 1,8 of the 44 SOEs we analysed are members of the United Nations Global Compact (UNGC) - an initiative encouraging corporations to respect all human rights inter alia.

-- Insert Table 1 about here --

As human rights can be considered a key element of both CSR (e.g. Wettstein, 2012, p.745) and sustainable development, we reviewed the content of the SOE's CSR/sustainability reports from 2007-2010, and relevant sections of their websites (in both English and Chinese), for evidence of explicit and implicit reference to human rights. The use of company reports to analyse CSR actions and intentions is a key source of data for researchers (e.g. Chapple and Moon, 2005), and so too are corporate websites, which are increasingly used to detail CSR activities and outputs (Hamann, Sinha, Kapfudzaruwa, \& Schild, 2009; Noronha et al., 2013). However, we also recognize that corporate reports (whether paper or digital) are not necessarily accurate, and can be subject to bias, public relations spin, and so on (Muthuri and Gilbert, 2011). Nevertheless, we posit that such risks are mitigated by the fact that corporate reports are publicly scrutinised, and that it can be in a company's self-interest (e.g. reputational or branding interests) to avoid making false claims, and to uphold basic reporting standards (Chapple and Moon, 2005; Hamann, et al., 2009).

To determine the nature and extent of reported human rights concern, we conducted a content analysis of the SOEs' CSR/sustainability reports and websites with regard to 33 separate human rights that we derived from the ICCPR and ICESCR (see Tables 3a \& 3b below), and the 'Human Rights Translated' guide (Castan Centre, 2008). To enable a systematic review of the evidence, we developed key indicators (see Table 2 for some examples) under four categories: i) Policies: e.g. evidence of defined commitments and parameters of engagement with regard to each human rights; ii) Processes: e.g. evidence of management systems, training, and/or stakeholder-engagement processes 
related to each human rights issue; iii) Monitoring and Accountability: e.g. evidence of impact assessments; and iv) Reporting and Communication: e.g. evidence of reports that are comprehensive and material.

Importantly, the same reported concern was sometimes considered relevant to more than one human right (for human rights often overlap). The reported concerns were rated in terms of whether or not they provided convincing evidence with regard to each of the four categories. More specifically, a score of 1 was awarded for evidence of policies; 2 for policies and processes; 3 for policies, processes, and monitoring and accountability; and 4 for policies, processes, monitoring and accountability, and reporting and communication. Hence, the score range of 0 to 4 depicts the extent of disclosure on each of the human rights. The rating procedure was completed independently by each of the authors and our research assistant, and any discrepancies discussed and reconciled. The companies were then ranked based on their total human rights score (see table 4 below).

-- Insert Table 2 about here --

\section{RESEARCH FINDINGS}

We organize our findings as follows. First, we present the Chinese SOE's reported concern with civil and political rights. Second we present their reported concern with economic, social and cultural rights. Third, we identify the reported drivers and motives to contextualize the reported human rights concerns.

\section{Civil and Political Rights}

The Civil and Political Rights listed in the ICCPR refer to such things as equality before the law, freedom from servitude, and the right to freedom of conscience and public participation. They tend to be more 'negative' than the economic, social and cultural rights listed in the ICESCR: in that they often only require restraint on the part of would be offenders. Whilst primarily directed towards states, all civil and political rights can be impacted upon by businesses in a more or less direct fashion. For example, and although it is unlikely that companies can directly impact upon the right to recognition as a person before the law, businesses can be complicit in abuses of this right by third parties: e.g. if they (indirectly) benefit from, or support, property acquisition laws that treat the property of women as the property of their husbands. 
As to what the SOEs reported, we first note that the information disclosed on civil and political rights tended to be broad and lacking in detail. Further, and as is evidenced by their not being included in Table 3a, none of the SOEs referred to eight civil and political rights at all, namely: the right of detained persons to humane treatment; the right of aliens to due process when facing expulsion; the right to a fair trial; the right to be free from retroactive criminal law; the right to recognition as a person before the law; the rights of protection of the family and the right to marry; the rights to freedom from war propaganda, and freedom from incitement to racial, religious or national hatred; and the right to not be subject to imprisonment for inability to fulfill a contract.

The group of civil and political rights that generated the next lowest scores - and that were often reported upon in an overlapping and vague fashion - included the right not to be subjected to torture, cruel, inhuman or degrading treatment; the right not to be subjected to slavery, servitude or forced labour; the rights to life, liberty and security of person; the right to freedom of movement; the rights to freedom of thought, conscience and religion; the right to freedom of assembly; the right to equality before the law, equal protection of the law; and the rights of minorities. Of the 44 SOEs, no more than 10 reported on any one of these eight rights, and the reports that were made with regard thereto, tended to be broad statements of intention or commitment.

In terms of religious freedom, for example (the fifth of the above mentioned rights), the SOEs referred to such things as employment practices that were religiously non-discriminatory more than they did to the actual capacity to practice religion (e.g. through providing space for worship). Thus, the likes of Sinopec Group state that their "Chinese employees fully respect the religious belief and habits of foreign counterparts" (www.sinopecgroup.com), and CNOOC that it respects "differences and diversity in gender, age, disease, race and religion. [And that it...] ensure[s] no system and practices have discrimination tendencies" (2007 Sustainability Report, p.48). Further, and in referring to the eight human rights listed above more generally once again, we emphasize that only a handful of companies - e.g. COSCO Group and COSCO Shipping Company - went beyond statements of intention or commitment, and reported upon the existence of policies, processes, and/or systems, in which specific roles and responsibilities were detailed (e.g. the role and responsibilities of security guards in armed conflicts). 
We next note that around a third of the SOEs paid attention to each of the right to privacy; the right to freedom of association; the rights of protection for the child; and the right to participate in public life. Most of these rights, however, were reported on at a low level (as represented by the predominance of $1 \mathrm{~s}$ and $2 \mathrm{~s}$ in these table columns). Further, the reported concern with these rights focused on employees, trade-union related structures, and processes facilitating freedom of association and collective bargaining (these points are further discussed in the following section).

The remaining civil and political rights were each reported on by more than $50 \%$ of the SOEs. This last group includes the right to self-determination; the right to non-discrimination; the right to life; and the right to freedom of opinion and expression. At the most general level, we note that the first of these rights - the Right to self-determination (which, like the right to non-discrimination, is also contained in the ICESCR) - refers to the right "of peoples to determine their political status and... place in the international community" (Castan Centre, 2008: 3). We took evidence of policies and processes of stakeholder and community consultation over various issues (e.g. local resources and land usage) to constitute a general concern with self-determination. However, we also found no evidence of SOEs consulting with traditional peoples (or minority populations) in ways that would enable some sort of national independence (or sovereignty).

Reported concern with the right to non-discrimination was generally quite low. Nevertheless, some of the SOEs went into relative detail. In particular, COSCO Group (2008 Sustainable Development Report, p.152) noted that "Among 130 members of top management of second-tier companies, 9 are females...; six are aged below $40 \ldots$; two are non-party members...; one is of minority nationality... [and that] COSCO Group has 4,188 foreign employees, of which, 1,665 are females, accounting for $40.9 \%$ ". By way of contrast, many of the SOEs performed better in terms of their reported concern with the right to life (e.g. their various occupational health and safety and product safety standards) and the right to freedom of opinion and expression. Importantly, we observe that given various reported incidences in the popular media on violations regarding these rights in China more generally (e.g. Noronha et al., 2013: 29), these scores are likely to be over-stated.

To conclude this first section of analysis, the findings reveal that not one of the SOEs scored the maximum of 4 for any of the civil and political rights, and that the right to life and the right to non- 
discrimination received the highest average scores of $\sim 1.7$ each. More generally, most SOEs only had evidence of policies and/or processes in place for the majority of civil and political rights that they reported concern with, and there was negligible evidence of monitoring and accountability (and none for reporting and communication).

-- Insert Table 3a about here --

\section{Economic, Social and Cultural Rights}

In contrast to civil and political rights, economic, social and cultural rights tend to be more 'positive': for they require the possession of specific goods (and not just negative freedom from constraint, and/or, the restraint of potential infringers). The economic, social and cultural right to enjoy just and favourable conditions of work was the most reported upon of the ICESCR rights, and the most reported upon right overall. It received a total score of 105 points, which amounts to $60 \%$ of the 176 points possible (see table 3b). This right relates to a broad range of provisions: e.g. remuneration, working hours, workplace violence and harassment, paid holiday (including maternity/paternity leave), period rest at work, type of work (e.g. part- or full-time). Our analysis revealed that all 44 SOEs expressed their commitment to provide employees with just and favourable working environments, and that SOEs made policy statements related to employees' entitlement to a 'living wage' (which, in turn, was commonly linked to the paying of a minimum wage). Although companies mentioned leave days, very few disclosed their vacation structures and/or systems in detail. COSCO Group provided one exception by detailing its vacation structure in its 2010 sustainability report (p.263), and by noting the number of days employees were entitled to take under various categories: e.g., maternity leave (90 days), marriage leave (3 days), paternity leave (15 days), funeral leave (3 days).

The right to non-discrimination (which we have discussed above) was also reported on by all 44 SOEs. In contrast to the right to enjoy just and favourable conditions at work, which received 105 (60\%) of the total points possible, it received a total of 76 (43\% of 176). 93\% of the SOEs reported on the right to education, $91 \%$ on the right to health, $84 \%$ on the right to social security and the right to an adequate standard of living, and $70 \%$ on the right to self-determination (which we have discussed above once again). The initiatives reported on in these regards were both inward facing (i.e. related to 
employees) and outward facing (i.e. related to the general public). To provide some further specifics, we note that reported concerns with the right to health, tended to focus on physical health and working conditions. Nevertheless, China Oilfield Services Limited (COSL) also reported on the mental health of its workers when it stated that:

“In addition to physical health, COSL also cares about staff's psychological health. It provides staff with psychological health tutorials with the help from members of the Association of Psychological Health, State Professional Psychological Consultants (2010 Social responsibility, www.cosl.com.cn)

Whilst less often reported on, it was not uncommon for SOEs to refer to the more general right to work, and the right to form trade unions and strike. $45 \%$ of SOEs for instance, claimed that workers had the right to join trade unions, and emphasized that employees had avenues for consultations through such structures as 'Labour Union Committees' and 'Employee Representative Congresses'. The SOEs did not disclose information related specifically to the right to strike (which is combined with the right to unionization). This lacuna, however, is not altogether surprising: for SOEs are widely reported to have discouraged strikes and to have intimidated workers previously (e.g. Downs, 2008). Furthermore, any mention of the right to form trade unions needs to be qualified by the fact that independent trade unions remain illegal in China.

Whilst the relatively low reporting of the right to take part in cultural life is perhaps not surprising, the relatively low levels of reporting on the right to a family life are somewhat out of sync with the emphasis on just work conditions. Nevertheless, a number of companies did report that they had maternity leave policies pegged just over the government's 14 weeks maternity leave allowance. Further, the likes of CNPC, CIMC, and CNOOC Group provided maternity insurance; and COSCO Group reported that they had implemented appropriate working environments for pregnant and lactating female employees (2010 Sustainable Development Report, p. 290).

To conclude our analysis of economic, social and cultural rights, we highlight that a number of SOEs reported the highest possible level of concern (i.e. 4 points) for the right to enjoy just and favorable conditions of work, and that this right received an average score of $\sim 2.4$ (the highest of all the human rights). Further, and whereas the average score reported for all of the ICCPR rights that 
were actually reported on was $\sim 0.6$ (i.e. excluding the 8 ICCPR rights that were not once referred to), the overall average for all of the ICESCR rights was double at $~ 1.2$.

-- Insert table $3 \mathrm{~b}$ about here --

\section{Why Chinese SOEs Report on Human Rights: Motives and Drivers}

Just as states and corporations can potentially be motivated to encourage or engage in CSR activities for a variety of reasons (e.g. Aguilera at al., 2007), so too can SOEs. In this section, we outline whether or not the reported human rights concerns of the SOEs can be linked to transnational, national, and/or intra-organizational drivers.

Transnational human rights pressures: As table 4 summarizes, only 7 of the SOEs managed to achieve more than $25 \%$ of the total points possible for their reported concern with all of the human rights (i.e. 33 or more of the 132 possible). Nevertheless, of these 7, 4 were active UNGC members, and one (i.e. CMCC), a non-communicating UNGC member. The highest score of $53(40 \%)$ was achieved by the parent SOE COSCO, a UNGC member. Notably, and whilst three UNGC members scored less than $25 \%$ of the total score possible - i.e. Petrochina Company Limited (24\%), CNOOC (21\%) and Sinochem International Corporation (16\%) - all of the UNGC SOEs were placed in the top half of the table. Further, all of the SOEs with scores totalling $23 \%$ or more (i.e. the top 10 performers), were involved in shipping (part of the COSCO Group), petroleum (part of the Sinopec, CNPC or CNOOC groups), or telecommunications (part of the China Mobile Group).

-- Insert Table 4 about here -

It was interesting to observe that the mention of human rights by some SOEs (e.g. COSCO Group) was sometimes framed in the language of the 'Protect, Respect and Remedy' framework, even though Ruggie's framework was rarely referred to explicitly. COSCO Group, for example, wrote that:

"Recognition and respect for human rights are essential to the rule of law and social justice and equity, and are fundamental to basic social systems such as the judicial system. States have the responsibility and obligation to respect, protect and practice human rights. Organizations are obligated to respect human rights, including respect for human rights within their sphere of influence." (COSCO Group 2010 Sustainability Report: 93; emphasis ours). 
Additionally - and despite their not being a UNGC member - the likes of China Mobile Ltd. refer to the 10 UNGC principles in its sustainability reports, and gives guidance on where various UNGC principles are reported upon (e.g. China Mobile Ltd 2009 Sustainability Report). Further, many of the SOEs appeared mindful of the need to comply with international regulations more generally. As COSCO Group note once again for example:

"In 2008, COSCO Group has received "International Ship and Port Safety Rules" (ISPS) checks for 774 times, passing rate reached $100 \%$. Since COSCO Group ships docked at various countries with different customs and conditions, crews are required to strictly follow ISPS rules, conscientiously study and grasp the non-invasive security check operation. It was required not to miss any clues, and to avoid being accused of violations of human rights" (2008 Sustainable Development Report: 143, emphasis ours).

Similarly, most SOEs professed concern to discharge duties associated with various 'soft' international instruments that have been (officially or unofficially) sanctioned by the CCP: e.g. the International Labor Organization Convention on child labour and minimum age requirements, various International Standard Organization initiatives. Both COSCO Group (2010: 254) and CMCC (2008: 16) for example, noted their implementation of ISO standards relating to privacy (i.e., to ISO 17799 and ISO 27001 respectively). To be clear, then, whilst the Chinese SOEs reported concern with transand inter- national pressures more generally, very few of the SOEs acknowledge the importance of conforming to the transnational pressure to respect all human rights in particular.

National human rights pressures: In contrast to transnational human rights pressures, the Chinese national government appears to have been a much more important and explicit driver of the SOEs' reported concern with human rights. At the World Economic Forum in Davos 2008, for example, Wang Jianzhou, the CEO of CMCC, acknowledged the SOE's role in helping China's Public Service Bureau access private information on their customers whenever they needed it (The Epoch Times, 2008). More generally, the SOEs suggested that their reported concern with human rights was motived by the concern to comply with national laws and regulations of the People's Republic of China (PRC), and international conventions endorsed by the Chinese government. PetroChina provide a good illustration in this regard when they write: 
"We strictly adhere to the Labor Law of the People's Republic of China, Labor Contract Law of the People's Republic of China and other relevant regulations of jurisdictions in which our shares are listed and we rigorously fulfill international conventions endorsed by the Chinese government." (Italics in original, 2008 CSR Report: 35).

In addition to these considerations, more or less all of the SOEs reported that it was their duty to support government policy on 'implementing scientific outlook on development' and 'building a harmonious society', and expressed their concern to create CSR policies with 'Chinese characteristics'. China Mobile Ltd., for example, stated that:

"The concepts of "scientific development" and "social harmony" are explicit expectations of societal development. Scientific development emphasizes putting people first, and promotes a holistic, comprehensive, balanced and sustainable approach to development; social harmony is socialism with Chinese characteristics...." (China Mobile Ltd 2007 CSR Report: 25).

Intra-organisational human rights pressures: Whereas the motivational importance of the Chinese government was clearly evident throughout the SOE reports, the importance of SASAC was not so explicitly evident. Nevertheless, the likes of Sinopec Group (Sustainable Development Report, 2010: $54,63,65)$ noted their concern to ensure that they complied with SASAC policies regarding external donations; made a point of their corporate website being ranked $3^{\text {rd }}$ in the SASAC annual analysis; and noted that "62 teams and 62 employees of Sinopec were awarded the honorary titles of "Red Flag Team" and "Exemplary Employee" by SASAC". In addition to being consistent with Chinese governmental policy more generally, the manner in which the SOEs refer to the need to implement the 'scientific outlook on development', to 'build a harmonious society', and to create CSR policies with 'Chinese characteristics', is consistent with the previously discussed SASAC guidelines. We also observe that just as the SASAC guidelines fail to mention human rights at all, so too did many of the SOE reports: for example, the second highest ranked SOE overall, Sinopec Corp., fail to explicitly mention 'human rights' once in the body of their 2010 Sustainable Development Report (but do mention it three times in a table related to reporting). However, we note that SASAC's reference to a 'human-oriented' policy may imply some considerations of human rights (see also Brownell, 2012). 
In addition to parent and subsidiary SOEs reporting on human rights in a fashion resembling the SASAC guidelines, a number of the SOE subsidiaries reported on human rights concerns in a similar fashion to their parents. China Mobile Ltd., for example, refers to the 10 UNGC principles in its sustainability reports (e.g. 2009) despite not being a member of the UNGC itself. This is likely related to the fact that their parent, CMCC, is a member of the UNGC. Similarly, the fact that COSCO Shipping Company and China COSCO Holdings Company both ranked in the top 7 companies despite their not being members of the UNGC, is likely related to the fact that their parent SOE, COSCO, was the highest ranked SOE overall. In noting as such, however, we do not wish to suggest that SOE subsidiaries only performed relatively strongly when their parents did likewise. Indeed, only four of the eight parent SOEs (i.e. CMCC, $\mathrm{CRHC}$, COFCO and COSCO) managed to perform better than all of their subsidiaries.

\section{DISCUSSION}

Our analyses reveal three points of particular importance. First, the extent to which the Chinese SOEs reported concern with the economic, social and cultural rights listed in the ICESCR surpassed their reported concern with the civil and political rights listed in the ICCPR. Indeed, the average score the SOEs received for their reported concern for all the ICESCR rights was $\sim 1.2$, double the $\sim 0.6$ average received for their reported concern with those ICCPR rights actually referred to. Further, and whereas 8 of the ICCPR rights were not referred to at all, all of the ICESCR rights were referred to by at least a few of the SOEs to some minimal extent. We also highlight that whilst none of the SOEs received a maximum score of 4 for any of the ICCPR rights, a number of SOEs received a score of 4 for the right to enjoy just and favourable conditions of work. This ICESCR right also received an average score of $\sim 2.4$, the highest of all the rights by some considerable margin - with the rights to non-discrimination (an ICCPR and ICESCR right), life (ICCPR), and education (ICESCR) being collectively placed second with average scores of $\sim 1.7$. In short, we emphasize that the SASAC SOEs reported concern with some rather than all human rights. This is consistent with pressures emanating from their national and intra-organizational environments (which emphasize the importance of ICESCR rights), and less consistent with those at the transnational level (which emphasize all of the ICCPR and ICESCR rights). 
Second, we note that whilst the importance of transnational pressures was somewhat muted overall, those SOEs within the UNGC, all placed in the top half of performers (see table 4). Accordingly, it seems that those SOEs that are more directly exposed to transnational pressures to acknowledge the importance of all human rights are more likely to report concerns that tend in this direction. Further, some of the SOE subsidiaries that did not themselves have direct connections to the transnational pressure to respect all human rights (e.g. COSCO Shipping Company), but that had intra-organizational connections to a parent SOE that did (e.g. COSCO Group), also performed relatively well.

Third, we highlight that - whilst the reported concern with ICESCR rights was relatively higher than that of the ICCPR rights; and that those SOEs with relations to the UNGC tended to perform relatively well - the extent to which the SOEs reported concern with human rights in general, was low in absolute terms. Indeed, only one of the rights - i.e. the right to enjoy just and favourable conditions of work - received an average of more than half the maximum score possible.

When taken together, these three points suggest that the idea that MNCs are commonly subject to national and intra-organizational pressures that can result in them resisting transnational pressures with regard to CSR issues more generally (e.g. animal rights; sustainable development), appears to also hold with regard to human rights issues in particular situations. Thus, and whereas international business (e.g. Kostova, Roth \& Dacin, 2008) and CSR scholars (e.g. Aguilera et al., 2008) have hitherto hesitated at extending the more general logic of multilevel (and fragmented) CSR pressures to human rights pressures in particular, we suggest that such hesitance is likely misplaced.

Our findings also shed light on Ruggie's (2008: para. 32) suggestion that states should find it easier to "induce a rights-respecting corporate culture... in State-owned enterprises." In particular, our findings suggest that states can pick and choose between the rights that a state-owned enterprise's culture respects. More generally, and contra those who suggest that 'globalization' is contributing to a significant decrease in state capacities (critically, see Whelan, 2012: 713-715), these findings suggest that at least certain states - e.g. China - remain particular potent actors.

Our findings also point towards the possible emergence of a new CSR terminology, and perhaps even a new conception (or conceptions) of CSR. Specifically, the manner in which many of the SOEs 
wrote of their concern to promote the 'scientific outlook on development', to 'build a harmonious society', and to create CSR policies and practices with 'Chinese characteristics', suggests that the Chinese party-state and SOEs are not simply adopting extant (and predominantly Western) understandings of CSR (Waddock, 2008: 106) and human rights (Ames, 1997). Rather, they may be consciously designing and constructing their own CSR and human rights perspective based on new CCP ideologies (see Shambaugh, 2008, chapter 6), and perhaps traditional Chinese values and philosophies (Brownell, 2012; Whelan, 2007).

More indirectly, our findings suggest that, if the Chinese party-state can induce a reported concern with specific human rights amongst those SOEs it exerts (more or less direct) control over, then perhaps it can do so with regard to other business organizations as well. There is a line of thought within international relations scholarship, for example, which suggests that those states that control the biggest markets (amongst other things), also control the rules of the inter- or trans- national business environment (e.g. Drezner, 2007). Accordingly, the Chinese party-state may be able to wield greater influence over CSR policies and practices within their own national environment, and within the transnational environment more generally, if the Chinese economy continues to grow.

Whilst our findings are theoretically and practically important for all of the reasons we have just mentioned, they are also constrained by a number of limitations. In the first instance, our findings are limited by their being focused on the reported human rights concerns of Chinese SOEs. Thus, and whilst we think our concentration on reported human rights concerns is valid, we also recognize that actual policies and practices can be de-coupled (Meyer \& Rowan, 1977) from those that are reported upon. To quickly illustrate the importance of this constraint, we note that our analysis of CNOOC Ltd. does not account for public media reports that the SOE has dispossessed Burmese peoples of land and undermined their right to self-determination (e.g. The Shwe Gas Bulletin, 2008, 2009). Similarly, in analyzing China Mobile Ltd.'s reported concern with the right to self-determination, we have not accounted for public media reports that the SOE deliberately cut off telecommunications to the Sichuan province where many Tibetan nationals are located (Kyodo News, 2009).

In addition to the preceding constraint, we recognize that our findings are limited by our deliberately focusing on one specific business form (i.e. the state-owned enterprise), and on one home 
country (i.e. China). Amongst other things then, the lack of an international comparative perspective - where the reported human rights concerns of SOEs from different home states are analyzed - means that the capacity to generalize our findings is limited. The fact that we have not sought to account for specific industrial considerations also limits the extent to which our findings can be generalized. And finally, the manner in which we have only briefly discussed the broader context within which the CCP came to power, and within which Chinese SOEs have emerged, means that we have not been able to fully explore such important considerations as the changing nature of SOE-employee relations upon the reported human rights concerns of Chinese SOEs (e.g. Hassard, Sheehan \& Yuxin, 2008).

\section{CONCLUSION}

In the present paper we have argued that the tendency to overlook the potential for MNCs to be subject to conflicting human rights pressures is rendered increasingly problematic by the growing global prominence of Chinese SOEs. More specifically, we have constructed a framework that differentiates between human rights pressures at three levels of analysis (i.e. at the transnational, national, and intra-organizational levels respectively), and used this framework to analyse the reported human rights concerns of Chinese SOEs. Our main finding is that, in predominantly reporting a concern with only some human rights (i.e. those contained within the ICESCR), Chinese SOEs appear more influenced by pressures at the national and intra-organizational level, and less influenced by transnational pressures that encourage them to report their concern with all human rights (i.e. those contained within the ICCPR and ICESCR).

Our findings and analysis suggest a number of streams of future research. First, our work highlights the need for more detailed and targeted analyses of Chinese SOEs with regard to human rights. Amongst other things then, future work might look into how the different strategic considerations, and different industrial settings, of the various SOEs, impacts upon their differing reported concern with human rights. Further, our work suggests the need to empirically investigate the extent to which the human rights concerns that the SOEs report upon are evident in actual policies and practices.

The paper also points towards the need for research that investigates the ways in which Chinese SOEs might help or hinder the development of those multi-stakeholder networks and/or international 
accountability standards (IASs) they do (or do not) participate within (Gilbert, Rasche \& Waddock, 2011). How, for example, does the participation of PetroChina in the UNGC impact upon the legitimacy of the UNGC given that its parent, and non-UNGC member, CNPC, continues to be accused of supporting a Sudanese government accused of genocide? (Investors Against Genocide website). On the other hand, how does the non-participation of Chinese SOEs in an IAS like the Extractive Industries Transparency Initiative (Chan, Lee \& Chan 2008: 13-14) diminish (or contribute to) its impact? Furthermore, and given that we have here focused on SOEs social disclosure, it would be interesting to see how the Global Reporting Initiative has impacted upon Chinese SOEs, and viceversa.

Our findings also point towards the need for comparative scholarship. Specifically, we suggest that the framework and methods we have here detailed provide a basis from which to begin establishing how different national and intra-organizational pressures impact upon the extent to which different businesses report concern with (or are actually concerned with) human rights. Clearly, such work is important to those who wish to build upon, add to, or more fully implement, Ruggie's (2011) Guiding Principles on Business and Human Rights.

Finally, the paper suggests two broad and overlapping lines of research that are deserving of considerable attention. First, there is a need to develop the fledgling literature on CSR and China (e.g. Moon \& Shen, 2010; Noronha et al. 2013). This could be done, for example, through more fully exploring the political-economic and normative considerations that inform the various CCP ideologies that the Chinese SOEs and SASAC are linking to CSR. Further, it would be very interesting for future work to look into whether or not the growing might of China and Chinese SOEs is having any impact on human rights pressures at the transnational level, and within other countries. This last line of research would likely prove of considerable interest throughout the social sciences. 


\section{REFERENCES}

Aguilera, R. V. \& Jackson, G. (2003). The cross-national diversity of corporate governance: Dimensions and determinants. The Academy of Management Review, 28(3), 447-465.

Aguilera, R. V. \& Jackson, G. (2010). Comparative and international corporate governance. The Academy of Management Annals, 4(1): 485-556.

Aguilera, R. V., Rupp, D. E., Williams, C.A. \& Ganapathi, J. (2007). Putting the S back in corporate social responsibility: A multilevel theory of social change in organizations. Academy of Management Review, 32(3), 836-863.

Ames, R. T. (1997). Continuing the conversation on Chinese human rights. Ethics \& International Affairs, 11, 177-205.

Arnold, D. G. (2010). Transnational corporations and the duty to respect basic human rights. Business Ethics Quarterly, 20(3): 371-399.

BBC (British Broadcasting Corporation) (2013). Jiang Jiemin: China sacks former energy chief. Issue date 03/09/2013 retrieved from http://www.bbc.co.uk/news/world-asia-china-23925370 on 20/11/2013.

Brownell, S. (2012). Human rights and the Beijing Olympics: Imagined global community and the transnational public sphere. The British Journal of Sociology, 63(2), 306-327.

Burns, J. P. (1999). The People's Republic of China at 50: National political reform. The China Quarterly, 159, 580-594.

Castan Centre (Castan Centre for Human Rights and Law, Monash University). (2008). Human rights translated: A business reference guide. Melbourne: Monash University.

CIMC (China International Marine Containers Group Ltd) (2010). 2010 Corporate Social Responsibility Report. Retrieved from http://www.cimc.com/en/about/csrreport/201106/P020110613544592714657.pdf on 13/09/2010.

Chan, H. S. (2009). Politics over markets: Integrating state-owned enterprises into Chinese socialist market. Public Administration and Development, 29: 43-54.

Chan, L-H., Lee, P. K., \& Chan, G. (2008). Rethinking global governance: A China model in the making?. Contemporary Politics, 14(1): 3-19. 
Chapple, W. \& Moon, J. (2005). Corporate social responsibility (CSR) in Asia: A seven-country study of CSR web site reporting. Business and Society, 44(4): 415-441.

China Merchants Group (2008). 2008 sustainable development report. Retrieved from http://ftp.cmhk.com/report/CMreport2008e.pdf on 12/08/2009.

CMC (China Mobile Communications) Corporation (2009). 2009 corporate social responsibility report. Beijing: CMCC.

China Mobile Ltd (2007). 2007 corporate social responsibility report. Retrieved from http://www.chinamobileltd.com/images/pdf/2008/crr/crr_2008_e_full.pdf on 24/10/2009.

China Vitae. (website). http://www.chinavitae.com. Accessed 14/03/2012.

Clinton, H. R. (2010). Remarks on internet freedom. Speech by U.S. Secretary of State. The Newseum, Washington, DC. January 21 2010. Retrieved from: http://www.state.gov/secretary/rm/2010/01/135519.htm on 20/03/2013.

CNOOC Ltd (China National Offshore Oil Corporation Ltd) (2007). 2006-2007 social responsibility report: Fulfil our promises for a brighter future. Retrieved from http://www.cnoocltd.com/encnoocltd/shzr/shzrbg/images/200933088.pdf accessed on 01/06/2010.

COSCO (China Ocean Shipping Group) (2010). 2010 sustainability report. Retrieved from http://www.cosco.com/gc_report/gc_report2011/PDF/中远集团 2010 年可持续发展报告-EN.pdf on $22 / 01 / 2011$.

COSL (China Oilfield Services) (2010). Employee development: 2010 social responsibility. http://www.cosl.com.cn/ens/Social/StaffDeve/2010-06-04/872.shtml on 02/01/2011.

Deng, Y. (2008). China's struggle for states: The realignment of international relations. Cambridge: Cambridge University Press.

Downs, E. S. (2008). Business interest groups in Chinese politics: The case of the oil companies. In C. Li (Ed.). China's changing political landscape: prospects for democracy (p. 121-141). Washington, D.C.: Brookings Institution Press.

Drezner, D. W. (2007). All politics is global. Princeton, N.J.: Princeton University Press. 
The Epoch Times (2008). China CEO confesses CCP's surveillance of mobile phones. Northern

California Edition, Feb 7-13 retrieved from www.theepochtimes.com.

Fewsmith, J. 2008. Staying in power: What does the Chinese Communist Party have to do? In Cheng Li (ed.), China's Changing Political Landscape: Prospects for Democracy, pp. 212-226.

Washington, D.C., Brookings Institution Press.

Fortune (2013). Fortune global 500 2005-2013. Retrieved from http://money.cnn.com/magazines/fortune/global500/ on 20/11/2013.

Gilbert, D. U., Rasche, A. \& Waddock, S. (2011). Accountability in a global economy: The emergence of international accountability standards. Business Ethics Quarterly, 21(1), 23-44.

Hamann, R., Sinha, P., Kapfudzaruwa, F., \& Schild, C. (2009). Business and human rights in South Africa: An analysis of antecedents of human rights due diligence. Journal of Business Ethics, 87 (2), 453-473.

Hassard, J., Sheehan, J., \& Yuxin, X. (2008). Chinese state-enterprise reform: Economic transition, labour unrest and worker representation. Capital \& Class, 32(3), 31-52.

Human Rights Watch (2003). Sudan, oil and human rights. Retrieved http://www.hrw.org/sites/default/files/reports/sudanprint.pdf on 30/06/2008.

Investors Against Genocide (website). http://www.investorsagainstgenocide.org. Accessed 19/05/2013,

Jamali, D. (2010). MNCs and international accountability standards through an institutional lens: Evidence of symbolic conformity or decoupling, Journal of Business Ethics 95(4), 617-640.

Kobrin, S. J. (2009). Private political authority and public responsibility: Transnational politics, transnational firms, and human rights. Business Ethics Quarterly, 19(3), 349-374.

Kong, D., Liu, S., \& Dai, Y. (2012). Environmental policy, company environment protection, and stock market performance: Evidence from China. Corporate Social Responsibility and Environmental Management. DOI: 10.1002/csr.1306

Kostova, T., Roth, K., \& Dacin, M. T. (2008). Institutional theory in the study of multinational corporations: A critique and new directions. Academy of Management Review, 33(4), 994-1006. 
Kyodo News (2009). Police on guard on Tibetan areas in China, phone lines cut: watchdog. www.english.kyodonews.jp on 03/02/2009.

McCorquodale, R. (2009). Corporate social responsibility and international human rights law. Journal of Business Ethics 87(Supplement 2): 385-400.

McGregor, R. (2010). The party: the secret world of China's communist rulers. London: Allen Lane.

Meyer, J. W. \& Rowan, B. (1977). Institutionalized organizations: Formal structure as myth and ceremony. The American Journal of Sociology, 83(2), 340-363.

Moon, J., \& Shen, X. (2010). CSR in China research: Salience, focus and nature. Journal of Business Ethics, 94, 613-629.

Morsink, J. (1999). The Universal Declaration of Human Rights: Origins, drafting, and intent. Philadelphia: University of Pennsylvania Press.

Muthuri, J. \& Gilbert, V. (2011). An institutional analysis of corporate social responsibility in Kenya. Journal of Business Ethics, 98, 467-483

Naughton, B. (2011). China's economic policy today: The new state activism. Eurasian Geography and Economics 52(3): 313-329.

Néron, P-Y. \& Norman, W. (2008). Citizenship, inc. Do we really want businesses to be good corporate citizens. Business Ethics Quarterly, 18(1), 1-26.

Noronha, C., Tou, S., Cynthia, M.I., \& Guan, J. J. (2013). Corporate social responsibility reporting in China: An overview and comparison with major trends. Corporate Social Responsibility and Environmental Management, 20, 29-42

OECD (Organisation for Economic Cooperation and Development) (2008). OECD investment policy reviews: China 2008. Paris: OECD.

OECD (Organisation for Economic Cooperation and Development) (2011). OECD guidelines for multinational enterprises: Recommendations for responsible business conduct in a global context. Paris: OECD.

Oliver, C. (1991). Strategic responses to institutional processes. Academy of Management Review, 16(1): 145-179. 
Patey, L. A. (2007). State rules: Oil companies and armed conflict in Sudan 2007 Third World Quarterly. 28(5): 997-1016.

Patey, L. A. (2009). Against the Asian tide: The Sudan divestment campaign. Journal of Modern African Studies, 47(4): 551-573.

Peerenboom, R. (2007). China nodernizes: Threat to the west or model for the rest. Oxford: Oxford University Press.

PetroChina (2008). 2008 corporate social responsibility report: Energise, harmonise, realise.

Retrieved from

http://www.petrochina.com.cn/resource/pdf/xwygg/2008shzrbg_en.pdf?COLLCC=2919122496\&

$\underline{\text { COLLCC }=2919122558 \& \text { COLLCC }=2919122543 \& \text { COLLCC }=2919122501 \& \text { COLLCC }=29191225}$

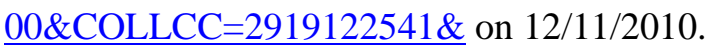

PetroChina. (2011). 2011 sustainability report. Retrieved from http://www.petrochina.com.cn on $05 / 4 / 2012$

PetroChina (2008). Corporate social responsibility report: Energise, harmonise, realise. Retrieved from http://www.petrochina.com.cn on 12/11/2010.

Rasche, A. (2012). Global policies and local practice: Loose and tight couplings in multi-stakeholder initiatives. Business Ethics Quarterly, 22(4): 679-708.

Ruggie, J. G. (2008). Protect, respect and remedy: A framework for business and human rights. Report of the Special Representative of the Secretary-General on the Issue of Human Rights and Transnational Corporations and other Business Enterprises, U.N. Doc A/HRC/8/5 (7 April 2008).

Ruggie, J. G. (2011). Guiding principles on business and human rights: Implementing the United Nations "Protect, Respect and Remedy" framework. Report of the Special Representative of the Secretary-General on the Issue of Human Rights and Transnational Corporations and other Business Enterprises, U.N. Doc A/HRC/17/31 (21 March 2011).

SASAC (State Asset Supervision and Administration Commission of the State Council) (2003). Interim regulations on supervision and management of state-owned assets of enterprises. Retrieved from http://www.sasac.gov.cn/n2963340/n13933222/13934025.html on 27/07/2012. 
SASAC (State Asset Supervision and Administration Commission of the State Council) (2008).

Guidelines to the state-owned enterprises directly under the central government on fulfilling corporate social responsibilities. Retrieved from http://www.sasac.gov.cn/n2963340/n13933222/14125651.html on 27/07/2012.

Scherer, A.G. \& Palazzo, G. (2011). The new political role of business in a globalized world: A review of a new perspective on CSR and its implications for the firm, governance and democracy. Journal of Management Studies, 48(4): 899-931.

Shambaugh, D. (2008). China's Communist Party: Atrophy and adaptation. Berkeley: University of California Press.

Shen, W., \& Lin, C. (2009). Firm profitability, state ownership, and top management turnover at the listed firms in China: A behavioral perspective. Corporate Governance: An International Review, 17(4): 443-456.

Shirk, S. L. (1993). The political logic of economic reform in China. Berkeley: University of California Press.

The Shwe Gas Bulletin (2008). Treasury sanction on Myanmar traffickers implicate CNOOC. FebMarch 2008. Published by the Arakan Oil Watch.

The Shwe Gas Bulletin (2009). Abuses continue as China and India battle energy interests in Burma. March-April 2009. Published by the Arakan Oil Watch.

SINOPEC Group (2010). Making every drop count: 2010 Sustainable development report. Retrieved from http://www.sinopecgroup.com/english/pages/sustainreport2010en.pdf on 12/11/2011.

Smith, J. (2013). Corporate human rights obligations: Moral or political?. Business Ethics Journal Review, 1(2): 7-13.

UNCTAD (United Nations Conference on Trade and Development) (2011). World investment report 2011. New York: United Nations.

UKFCO (United Kingdom Foreign \& Commonwealth Office) (2011). Human rights and democracy: the 2010 Foreign \& Commonwealth Office report. March. 2011. Retrieved from http://www.fco.gov.uk/en/global-issues/human-rights/around-the-world/human-rights-report $\quad$ on 01/08/2011. 
UN (United Nations). 1945. The charter of the United Nations. Retrieved from http://www.un.org/en/documents/charter/ on 10/10/ 2013.

UNGC. (United Nations Global Compact). Website. United Nations Global Compact. Retrieved from http://www.unglobalcompact.org on 25/07/2012.

Waddock, S. (2008). Building a new institutional infrastructure for corporate responsibility. Academy of Management Perspectives, 22(3): 87-108.

Wettstein, F. (2012). CSR and the debate on business and human rights: Bridging the great divide. Business Ethics Quarterly, 22(4): 739-770.

Wettstein, F. (2013). Morality meet politics, politics meet morality: Exploring the political in political responsibility. Business Ethics Journal Review, 1(9): 57-62.

Whelan, G.(2007). Corporate social responsibility in Asia: A Confucian context, in S. May, G. Cheney \& J. Roper (eds) The Debate over Corporate Social Responsibility, pp. 105-118, New York: Oxford University Press.

Whelan, G. (2012). The political perspective of corporate social responsibility: A critical research agenda. Business Ethics Quarterly, 22(4): 709-737.

Whelan, G. (2013). Political corporate social responsibility: Some clarifications. Business Ethics Journal Review, 1(10): 63-68.

Whelan, G., Moon, J. \& Orlitzky, M. (2009). Human rights, transnational corporations and embedded liberalism: What chance consensus? Journal of Business Ethics, 87 (Supplement 2): 367-383.

Zerk, J. A. (2006). Multinationals and corporate social responsibility: Limitations and opportunities in international law. Cambridge: Cambridge University Press. 
Figure 1 - A Three-Level Framework of Human Rights Pressures

\section{Transnational Pressures}

International Governmental

Organizations: e.g. the UN;

the OECD

International Non-governmental

Organizations: e.g. Amnesty,

Human Rights Watch
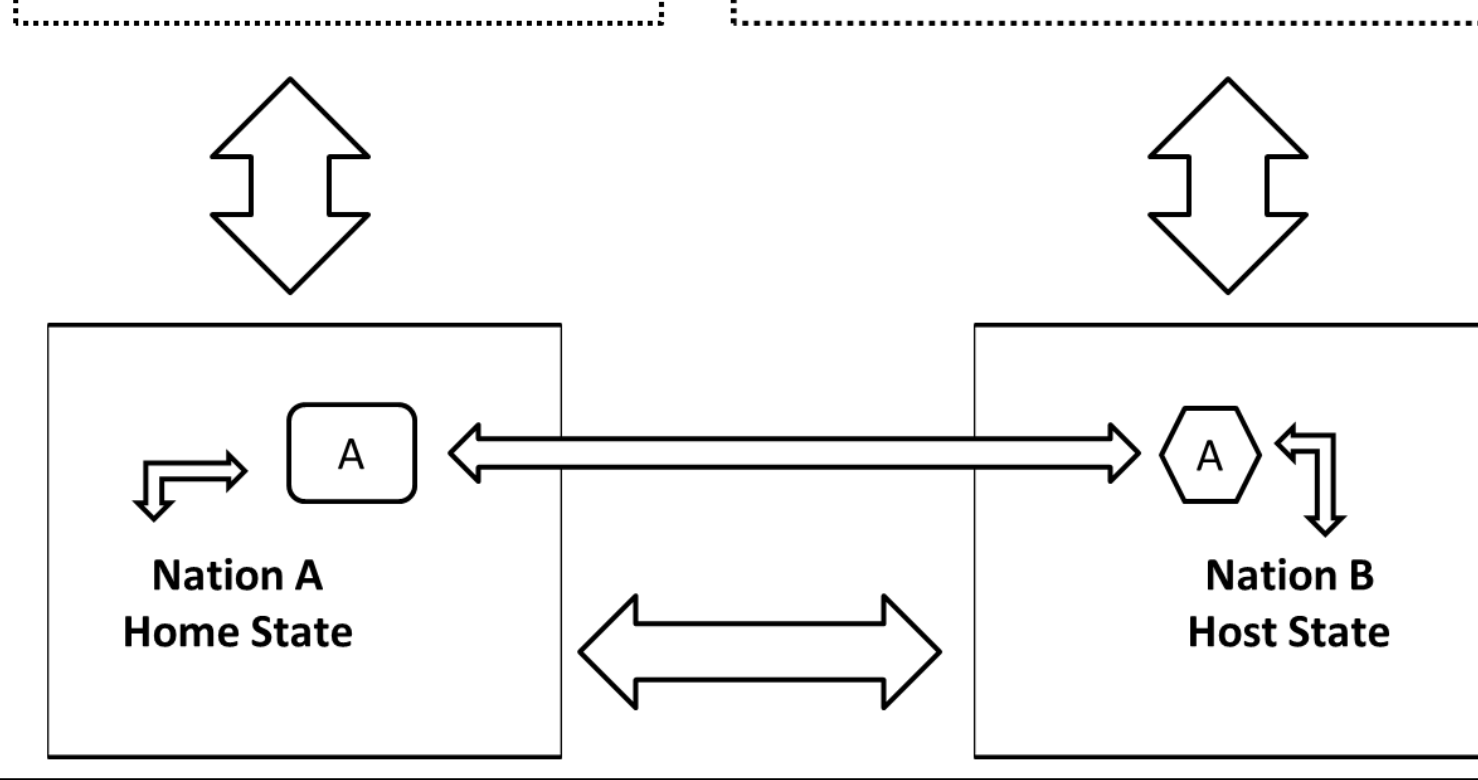

$\leadsto$ Pressure (Size not representative of degree) 
Table 1 - SOE's Transnational Membership to the UN Global Compact

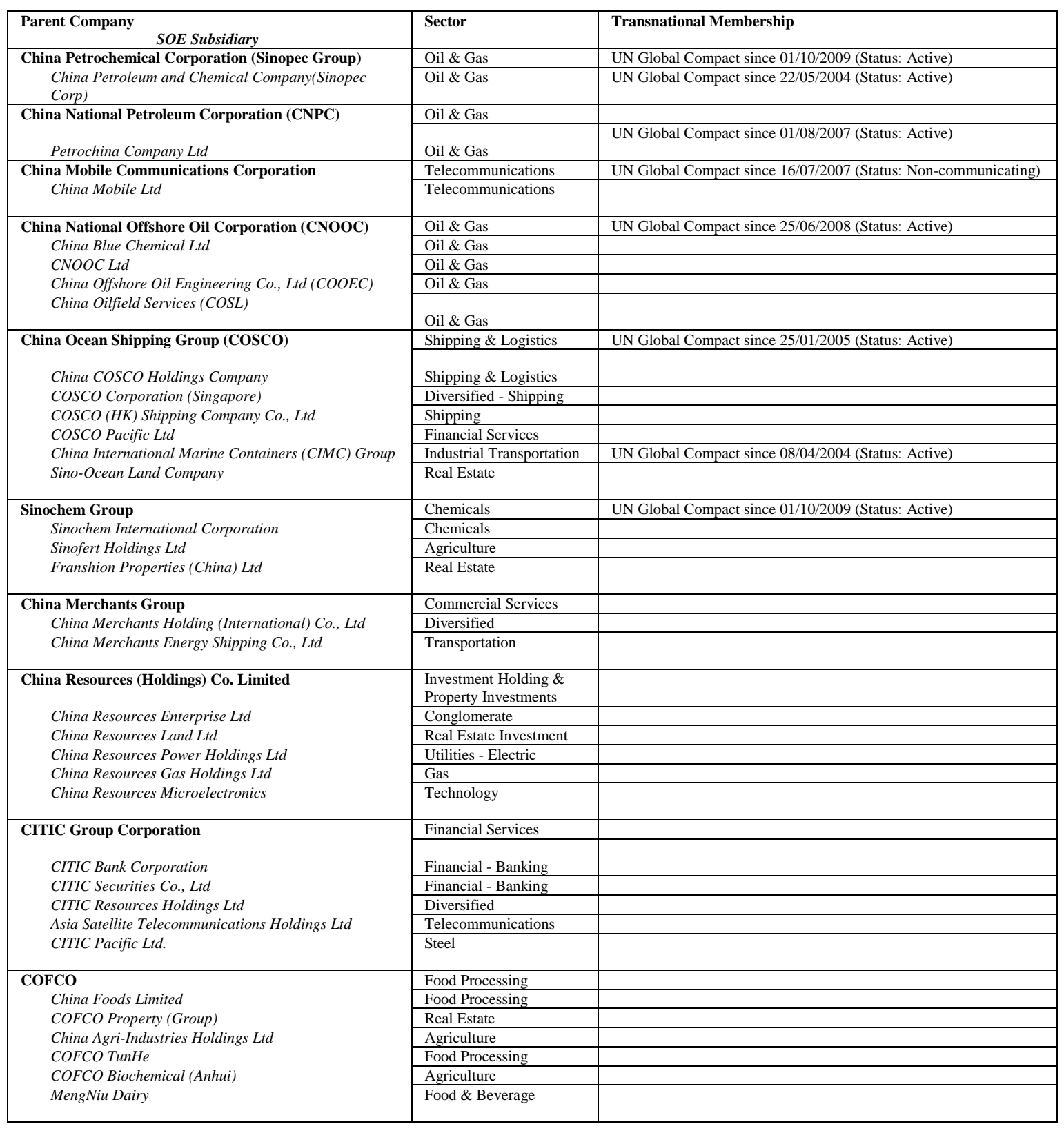


Table 2 - Examples of Human Rights Issues and Related Indicators

\begin{tabular}{|c|c|}
\hline Human Right Issue & $\begin{array}{l}\text { Indicators of evidence of expressions or reference to Human } \\
\text { Rights (HRs) }\end{array}$ \\
\hline $\begin{array}{l}\text { Non discrimination } \\
\text { (A labour right which } \\
\text { includes equality at work } \\
\& \text { equal pay for equal } \\
\text { work) }\end{array}$ & $\begin{array}{l}\text { - The company has commitments not to discriminate on the basis of } \\
\text { gender, disability, ethnic or racial status, age, religion, caste, } \\
\text { sexual orientation, union membership, political affiliation, } \\
\text { HIV/Aids, parental status } \\
\text { - The company has constituted management systems to ensure that } \\
\text { hiring, placement, remuneration, training are based on objective } \\
\text { factors and are implemented in non-discriminatory ways } \\
\text { - Company conducts impact assessment to determine risks to } \\
\text { employees and the company, and acts on the findings } \\
\text { - Company has a system of reporting and monitoring incidents of } \\
\text { discrimination and actions taken. The company uses external } \\
\text { auditors or other assurance processes to verify reported } \\
\text { information }\end{array}$ \\
\hline $\begin{array}{l}\text { Right to Health } \\
\text { (Both a labour right if } \\
\text { related to workplace health } \\
\& \text { safety; and also to } \\
\text { Physical and Mental } \\
\text { Health; and a non-labour } \\
\text { right if it goes beyond } \\
\text { employees to include other } \\
\text { programs with other } \\
\text { stakeholders) }\end{array}$ & $\begin{array}{l}\text { - Company has effective health and safety prevention and } \\
\text { remediation policies in place which comply with industry, } \\
\text { national and international standards } \\
\text { - Company has in place management systems, health and safety } \\
\text { procedures to protect employees against unhealthy, toxic or } \\
\text { harmful processes, substances and techniques } \\
\text { - Company routinely monitors its production processes, machinery } \\
\text { and equipment to ensure that they are safe and in good working } \\
\text { conditions. It conducts impact assessment and acts on its findings } \\
\text { - Company has health \& safety reporting and monitoring systems. } \\
\text { It uses external auditors or other assurance processes to verify } \\
\text { reported information }\end{array}$ \\
\hline
\end{tabular}


Table 3a - Chinese SOE Reported Concern with Rights listed in the ICCPR

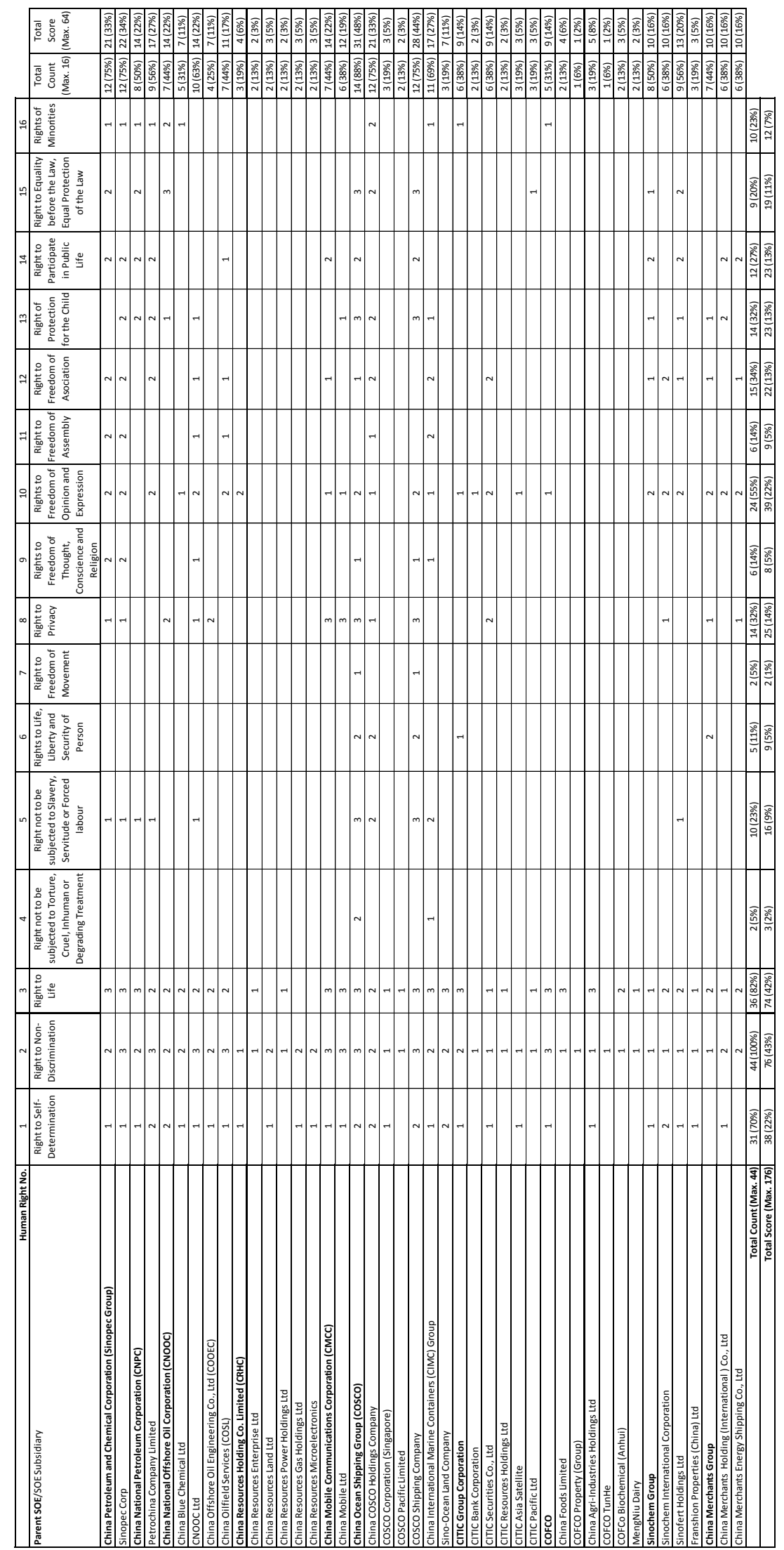


Table 3b - Chinese SOE Reported Concern with Rights listed in the ICESCR

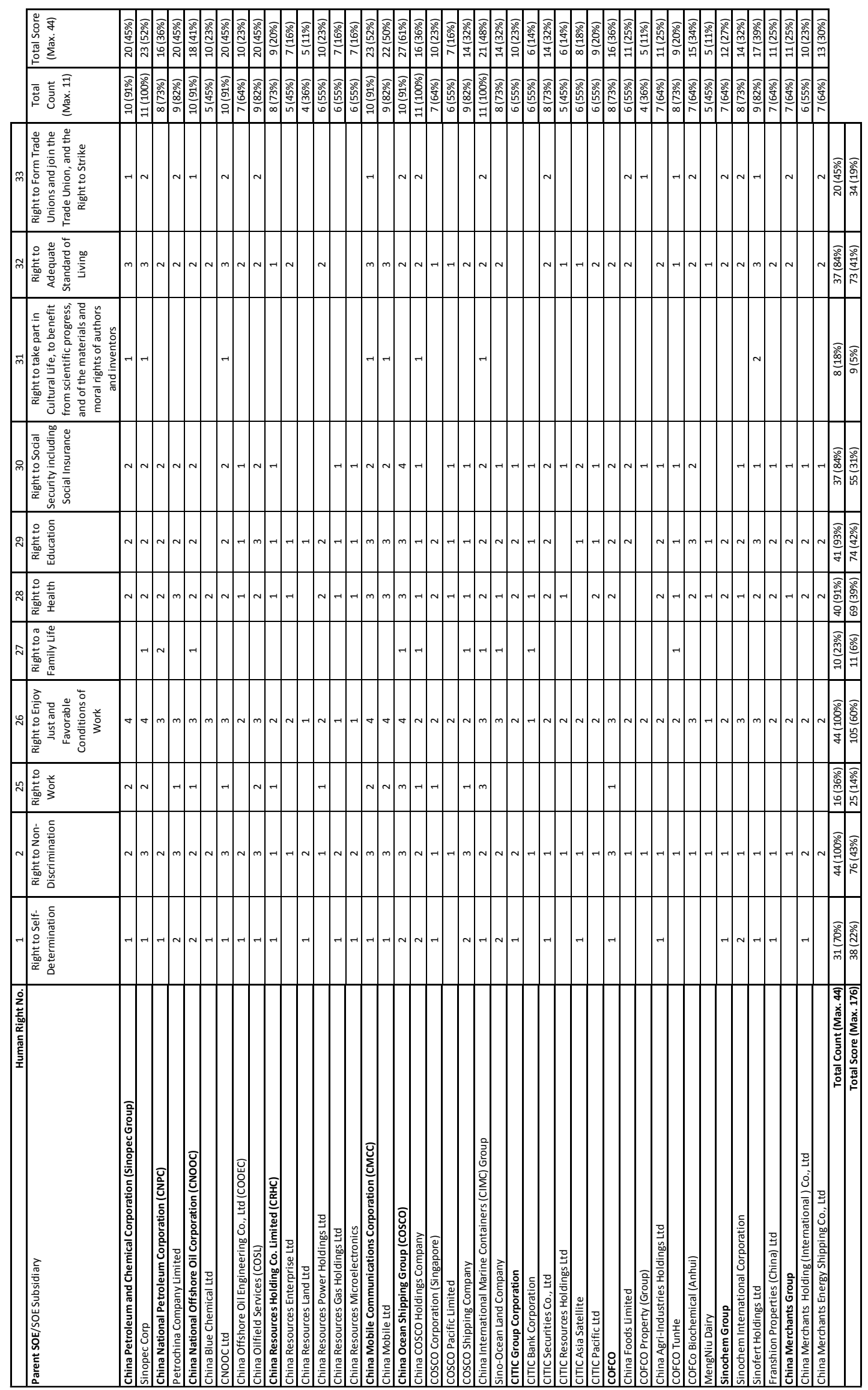


Table 4 - Ranking of Chinese SOEs on Reported Concern with Human Rights

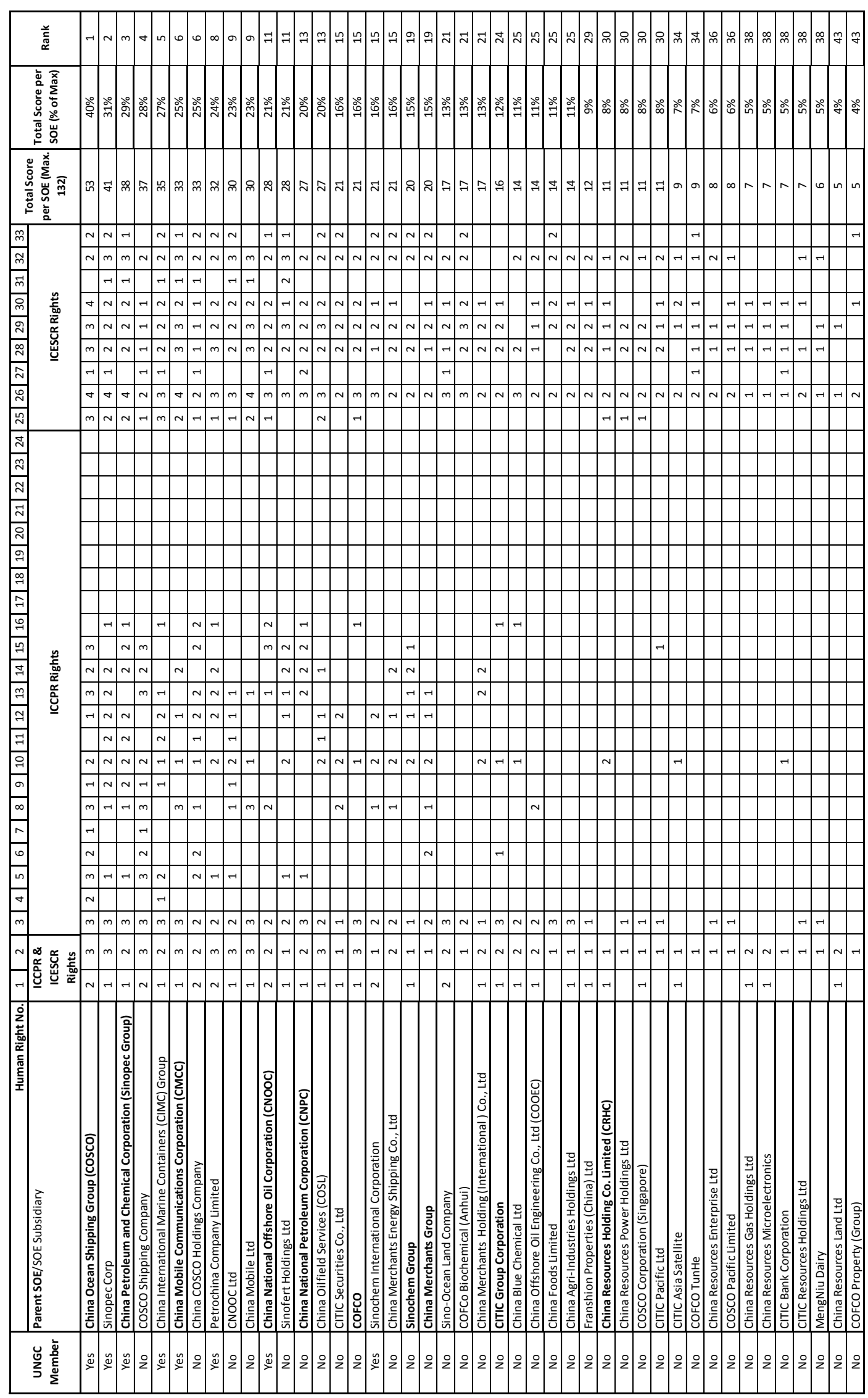

